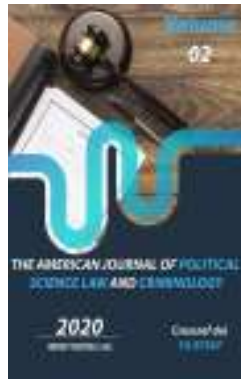

Journal Website: http://usajournalshub.c om/index,php/tajpslc

Copyright: Original content from this work may be used under the terms of the creative commons attributes 4.0 licence.

\section{Politics Of Uzbekistan In Solving Border Problems In Central Asia}

Oybek Ochilovich Sirojov

Doctor Of Political Science Department Of "Social-Political Science" Tashkent Chemical Technological Institute Tashkent, Uzbekistan

Baxtiyor Arabov

Researcher, Department Of "Social-Political Science" Tashkent Chemical Technological Institute Tashkent, Uzbekistan

\title{
ABSTRACT
}

The Central Asian states are located in the same geographical area and have a border problem. The roots of Central Asia's border issues go back to the 1920s. Each country has its own approach and policy on solving border problems. This article analyzes Uzbekistan's policy on resolving border issues.

\section{KEYWORDS}

Central Asia, cooperation, foreign policy, borders, delimitation, demarcation, state border, region, peaceful settlement of problems, multilateral cooperation, delimitation policy, foreign policy of the Republic of Uzbekistan.

\section{INTRODUCTION}

Central Asia covers an area of 4 million $\mathrm{km}^{2}$ and is a region that connects Europe with Asia. The Central Asian states are located in the same geographical area and have common geographical problems, including border problems. The roots of Central Asia's border issues go back to the 1920s. The current administrative-territorial division in the region was carried out on the basis of the decree of the Central Executive Committee of Turkestan "On administrative-territorial division" adopted in 1924, without taking into account the historical statehood and ethnic characteristics.

The demarcation of the region in the 1920 s was based on the interests of the former center and did not take into account the wishes of the 
local population. (Frunze's letter to Kuibyshev states that "it is necessary to exchange views with Ilyich, not with the locals.") [1]. As a result, post-independence delimitation and demarcation of borders have been controversial.

This problem became more acute at the end of the last century, when the security problem in the region came to the fore. The states agreed to set up state commissions to determine the boundaries. These commissions also met several times and reached agreements. However, these agreements became more declarative and did not solve the problem. To date, there are problems with the delimitation of the state border between Uzbekistan and Kyrgyzstan, Uzbekistan and Tajikistan, Tajikistan and Kyrgyzstan, Kazakhstan and Turkmenistan (for land borders). This, in turn, hinders the rational use of available natural resources in creating an integrated security system in the region. In addition, various riots and clashes in the border areas are further complicating the situation*. It is impossible to develop cooperation processes without overcoming these problems.

\section{THE MAIN FINDINGS AND RESULTS}

Located in the center of the region, Uzbekistan shares a common border with all Central Asian countries. Its length is more than 7,000 kilometers, including 2,356.31 kilometers with Kazakhstan, 1,476.12 kilometers with Kyrgyzstan, 1,296.9 kilometers with Tajikistan,

\footnotetext{
* On March 13, 2019, clashes between citizens of the two countries will take place as a result of protests over the construction of a road in the White River region on the border between Kyrgyzstan and Tajikistan. There will be casualties as a result of the clashes. On May 8,
}

1,831.49 kilometers with Turkmenistan and 143 kilometers with Afghanistan.

Different approaches to demilitarization and demarcation of borders with the countries of the region have emerged. If we look at this issue in the case of Uzbekistan and Kyrgyzstan, Uzbekistan proposes to rely on the documents of 1924-1928 in defining the border, while Kyrgyzstan proposes to rely on the documents of 1955 . As a result, the delimitation of borders between states has not been completed.

Prolonged spending on demarcation has had a serious impact on third-party interference, various conflicts, and cooperation. In particular, the fact that the Uzbek side mined the mountainous area bordering Tajikistan at the beginning of the new century for security reasons has caused protests from the Tajik side. It also resulted in the deaths of dozens of civilians. The untimely settlement of border issues has affected the development of territorial disputes between the Central Asian republics, as well as inter-ethnic relations. For example, regional disputes between Tajikistan and Kyrgyzstan, such as Isfara, Bobkent, Samarkand between Tajikistan and Uzbekistan, Bukhara, and Semipalatinsk between Kazakhstan and Russia, have been encouraged and supported by interested external forces.

To better understand the importance and necessity of regulating the issues of delimitation and demarcation of the borders of our country with its neighbors, it is expedient

2020, a shootout took place on the border between Tajikistan and Kyrgyzstan, as a result of which 3 Kyrgyz border guards and 2 Tajik citizens were injured. The conflict stemmed from an attempt to exploit the disputed area. 
to look at the history of their settlement. The process of negotiations with the Central Asian states on the delimitation and demarcation of the state borders of Uzbekistan began in 2000 in accordance with the Resolution of the Cabinet of Ministers of November 3, 1999 "On measures to define and equip the state border of the Republic of Uzbekistan."

This process continued until the signing of the above-mentioned border agreement with Turkmenistan in September 2000 in Ashgabat. On October 5, 2002, an agreement on the agreed part of the Uzbek-Tajik border was signed in Dushanbe.

One of Uzbekistan's largest regional neighbors is Kazakhstan. The border between Uzbekistan and Kazakhstan is 2,150 km. Diplomatic relations between the two countries were established as independent states after the agreement of November 23, 1992. The Days of Kazakhstan were held in Uzbekistan on May 2330, 1994, and the Days of Uzbekistan were held in Kazakhstan on May 20-27, 1995. The two leaders also exchanged visits. On October 31, 1998, Kazakhstan and Uzbekistan signed the Treaty of Eternal Friendship. As a result of bilateral cooperation, the delimitation of the borders between Uzbekistan and Kazakhstan has been completed. Thus, the disputed borders between the two countries were eliminated. So far, more than 170 bilateral agreements have been signed between the two countries.

However, 15 years of negotiations with other neighboring countries on strict border control have not yielded the expected results. Years of debates and even disagreements over issues that can be resolved rationally with the right approach have often led to disagreements and even border clashes.

Unfortunately, this has not only delayed the process of delimitation of borders, but also created artificial barriers to the development of relations between Uzbekistan and the countries of the region, and suffered mainly from ordinary citizens, especially those living near the border.

The situation in Uzbekistan's relations with neighboring republics has necessitated a review of areas of bilateral cooperation and a change in approaches to delimitation of borders, the establishment of border checkpoints. By the end of 2016, the situation began to change dramatically. The new political leader in Uzbekistan has begun to pursue a policy of resolving the issue through compromise and mutual agreement with neighbors.

At a joint session of the Oliy Majlis in 2016, President Shavkat Mirziyoyev identified the development of cooperation with its neighbors in Central Asia as a priority of Uzbekistan's foreign policy. This was an important step towards intensifying the process of negotiations with neighboring countries on the legalization of the state border.

Acceleration of the issue of legalization of the border is also reflected in the program of measures for the implementation of the Action Strategy for the further development of the Republic of Uzbekistan.

This soon began to bear fruit. On the instructions of the President of Uzbekistan, it was decided to hold talks with neighboring countries on the delimitation and demarcation of borders on the basis of three main 
principles. The first is a strict consideration of mutual interests, the second is a well-thoughtout reasonable compromise, and the third is an equal exchange of plots of land. All parties agreed that it would not be possible to regulate borders without adhering to these principles, as all Central Asian countries had inherited confusion over the issue from the previous system.

Negotiations and joint field research, study of archival documents, cartographic materials revealed problems that complicate the state border with neighboring countries.

The first and most important problem is the lack of a legal basis for the delimitation of state borders with almost all Central Asian countries.

The second problem - 1924-1927 - was the period of delimitation of the Central Asian republics and disagreements over the documents adopted in 1930 and beyond.

The third problem was that the boundary lines marked on the maps did not match the location of the lands actually used, irrigation networks, many infrastructure facilities, households, and cemeteries.

In subsequent negotiations and in resolving the issue, the following factors began to be taken into account.

During the state visits of President Shavkat Mirziyoyev to the neighboring republics, the border issue was given priority and certain agreements were reached. In particular, during the state visits to the Kyrgyz Republic on September 5, 2017 and the Republic of Tajikistan on March 9, 2018, the signing of the agreed part of the agreement on the UzbekKyrgyz state border and some sections of the
Uzbek-Tajik border is important in delimitation and demarcation of the border. earned. Thanks to the open and pragmatic policy of Uzbekistan, an agreement has been reached on the demarcation of the state border between Uzbekistan, Kazakhstan and Turkmenistan. A relevant agreement was signed in November 2017 at the High-Level International Conference on Central Asia in Samarkand [2].

The decree of the President approved the priorities for the development of foreign policy and foreign economic cooperation of the Republic of Uzbekistan with key foreign partners in the medium term. According to him, one of the priorities of our foreign policy is to complete the process of delimitation and demarcation of the state border of Uzbekistan.

In recent years, along with the intensification of cooperation between Uzbekistan and foreign countries, the process of negotiations with Central Asian countries on the delimitation and demarcation of borders has become more regular. For example, if we talk about agreements with neighbors in this regard. An agreement on the state border with Turkmenistan was signed in Ashgabat in September 2000, in which it was agreed to continue work on 10 sections. In accordance with the high-level agreement reached in Ashgabat during the state visit of the President of our country to Turkmenistan in March 2017, the negotiations of working groups on border issues were resumed after a long break.

Uzbekistan has signed an agreement with Kyrgyzstan on delimitation of the border. Tashkent has even agreed to help build a hydroelectric power plant on the Naryn River. One of the important results of Shavkat 
Mirziyoyev's visit to Bishkek was the restoration of checkpoints in the Fergana Valley and the facilitation of movement between the two countries.

In February 2018, during a meeting with Afghan officials, the issue of strengthening the border line along the banks of the Amu Darya was discussed. The regulation of Uzbekistan's borders with neighboring countries has received positive recognition not only in the region and the CIS, but also around the world.

From August 2016 to August 2018, the Uzbek government delegation held a total of 65 meetings with government delegations from neighboring countries, including 18 with Kazakhstan, 28 with Kyrgyzstan, 9 with Tajikistan, 9 with Turkmenistan, and 1 with Afghanistan. The delimitation of the state border with Kazakhstan has been completed and the demarcation process is underway.

\section{CONCLUSION}

In general, through the open policy of President Shavkat Mirziyoyev, based on good neighborliness and friendship, the most difficult issue that has accumulated over the years and hindered the development of relations with neighboring countries, began to find a solution to the border problem.

The border agreements signed with Kyrgyzstan and Tajikistan have opened wide opportunities for our country to develop modern economic cooperation, increase trade and cross-border trade, and, most importantly, to create historical conditions for the movement of blood relatives. Thanks to the lifting of border restrictions with Kyrgyzstan and agreements with Tajikistan on the full operation of border posts, the number of citizens crossing the Uzbek-Kyrgyz border every day is 30,000, and the number of people crossing the Uzbek-Tajik border is 20,000.

The signing of agreements on the UzbekKyrgyz and Uzbek-Tajik borders, as well as agreements on the territory of the junction of Uzbekistan, Kazakhstan and Turkmenistan has become a historic event in the life of our country. [3]

The work on completing the legal registration of the state borders of Uzbekistan with neighboring countries in the region is underway.

\section{REFERENCES}

1. Omemov M. Bartold V.V. On the national demarcation in Central Asia. // Central Asia and the Caucasus. 1999 No. 5 -S.43-52.

2. www.prezident.uz/uz/lists/view/1227

3. Sirojov O. Problems and solutions of human resources in Central Asia // Credo new. 2015 №2 C.-11.

4. Sirojov $O$. Regional integration and cooperation // Sotsiosfera 2015 №1 pp.129-131

5. Safoev S. Geopolitics of Central Asia. - T .: JIDU. 2005. 91-p.

6. Kocharov Ch. Problems of the regional integration process in Central Asia. Tashkent .: Fan. 2008. 114-p.

7. S. Frederick Starr Andrew C. Kuchins The Key to Success in Afghanistan A Modern Silk Road Strategy SILK ROAD PAPER May 2010 
The American Journal of Political Science Law and Criminology (ISSN - 2693-0803)

Published: November 19, 2020 | Pages: 15-20

Doi: https://doi.org/10.37547/tajpslc/Volume02Issue11-03

8. Speech by President of Uzbekistan Shavkat Mirziyoyev at the 72 nd session of the UN General Assembly http://president.uz/uz/lists/view/1063.

9. Iminov B.K. Interests are the source of politics and ideology. - T .: “Minxoj” 2002, 91-p.

10. Pozdnyakov E. National and International in Foreign Policy. International affairs 1992 № 4 . P.37. 